\section{Integrated Weed Management in Potato Using Straw Mulch and Atrazine}

\author{
Makhan S. Bhullar ${ }^{1}$, Simerjeet Kaur ${ }^{1}$, Tarundeep Kaur ${ }^{1}$, \\ and Amit J. Jhala ${ }^{2,3}$
}

ADDITIONAL INDEX WORDS. herbicides, percent control, Solanum tuberosum, tuber yield, weed biomass

Summary. Potato (Solanum tuberosum) is one of four major food crops in the world. Weed control is a major component in potato production and has been accomplished using different methods, including but not limited to the use of herbicides and straw mulch. A combination of preemergence herbicide and straw mulch may improve weed control; however, no information is available for combining both methods, along with their effects on weed control, weed density, and potato tuber yields. The objective of this study was to evaluate weed control in potato using atrazine or straw mulch applied alone at different rates or in combination. A field experiment was conducted for 4 years from 2006 to 2010 in Ludhiana, Punjab, India. Common weeds included burclover (Medicago arabica), common lambsquarters (Chenopodium album), littleseed canarygrass (Phalaris minor), purple nutsedge (Cyperus rotundus), scarlet pimpernel (Anagallis arvensis), swinecress (Coronopus didymus), and toothed dock (Rumex dentatus). Results suggested that atrazine applied alone was not very effective and resulted in $0 \%$ to $78 \%$ control depending on the weed species being investigated at 30 days after treatment (DAT). Straw mulch applied alone at any rate provided $\geq 90 \%$ control of toothed dock, but control of other weed species was variable. A combination of atrazine and straw mulch at any rate usually resulted in $>90 \%$ weed control at $30 \mathrm{DAT}$, except for swinecress and purple nutsedge. This treatment combination also resulted in weed density as low as 0 plant $/ \mathrm{m}^{2}$ for common lambsquarters, scarlet pimpernel, and toothed dock. Potato tuber weight and yield was significantly higher in all treatments compared with untreated control without difference among them. It is concluded that a combination of straw mulch and atrazine can provide effective weed control in potato.

$\mathrm{I}$ ndia is the second largest producer of potato in the world, contributing $\approx 10 \%$ of the world's potato production. In 2012 , potato was cultivated on 1.87 million hectares in India, with a production of 41.3 million tonnes (Government of India, 2013). Punjab is one of the largest potato producing states in India. In fact, potato cultivation occupies nearly $50 \%$ of the total area of vegetable crops in Punjab. Potato is a short duration crop; therefore, it fits in rotation with cereals, vegetables, pulses, or oilseed crops. Weed management is a challenge for potato producers because of a scarcity of labor for hand weeding and limited options for registered herbicides. Weed interference with the crop reduces marketable yield by decreasing

${ }^{1}$ All India Coordinated Research Program on Weed Control, Department of Agronomy, Punjab Agricultural University, Ludhiana, Punjab 141004 , India

${ }^{2}$ Department of Agronomy and Horticulture, University of Nebraska-Lincoln, Lincoln, NE 68583-0915

${ }^{3}$ Corresponding author. E-mail: amit.jhala@unl.edu. potato tuber number and size (Ahuja et al., 1999; Dallyn 1971; Nelson and Thoreson, 1981; Singh and Bhan, 1999). Weeds may also hinder mechanical harvest (Pandey, 2000; Wall and Friesen, 1990).

Critical period of weed control in potato is 20 to $66 \mathrm{~d}$ after emergence under irrigated conditions (Monteiro et al., 2011). Potato growers usually apply herbicide early postemergence and then it is followed by earthing up (inserting soil on both sides of the ridge with tractor-drawn implements, reshaping the ridges and covering potato roots and emerging tubers from direct sunlight), which also helps suppress late-emerging weeds. In the case of grass weed infestation, including littleseed canarygrass and wild oat (Avena fatua) at later stages, growers have been using graminicides. Hence, weed management programs in potato usually include at least one herbicide application and a mechanical operation in Punjab.

Potato growers in northwest India rely on triazine herbicides for weed control. Atrazine, a triazine herbicide, is applied preemergence as well as postemergence to control several broadleaf and some grass weeds primarily in maize (Zea mays), sorghum (Sorghum bicolor), and sugarcane (Saccharum officinarum). Atrazine is also applied in other minor crops, such as potato in India. However, sometimes atrazine persists for a long period of time in the soil and injures vegetable and pulse crops grown in rotation with potato. Potato is a winter season vegetable, planted in midSeptember to early October and harvested in January or February in northwest India. Lower temperatures during potato growing season increase the persistence of herbicides, including atrazine. Growers planting vegetable crops after potato harvest have reported atrazine injury in rotational vegetable crops, especially in cucurbits, one of the major spring and summer vegetable crops in northwest India. Atrazine applied at $2 \mathrm{~kg} \cdot \mathrm{ha}^{-1}$ in maize seeded in the first week of September resulted in the injury to the wheat (Triticum aestivum) crop seeded in the first half of November; with an interval of $<75 \mathrm{~d}$ between atrazine application and seeding wheat (Sharma and Sandhu, 1985). Metribuzin at $350 \mathrm{~g} \cdot \mathrm{ha}^{-1}$ applied to potato suppressed the growth of

\begin{tabular}{llll}
\hline $\begin{array}{l}\text { Units } \\
\begin{array}{l}\text { To convert U.S. to SI, } \\
\text { multiply by }\end{array}\end{array}$ & U.S. unit & SI unit & $\begin{array}{l}\text { To convert SI to U.S., } \\
\text { multiply by }\end{array}$ \\
\hline 0.4047 & acre $(\mathrm{s})$ & $\mathrm{ha}$ & $2.471 \mathrm{l}$ \\
0.0929 & $\mathrm{ft}^{2}$ & $\mathrm{~m}^{2}$ & 10.7639 \\
2.54 & inch $(\mathrm{es})$ & $\mathrm{cm}$ & 0.3937 \\
1.1209 & lb/acre & $\mathrm{kg} \cdot \mathrm{ha}^{-1}$ & 0.8922 \\
1 & $\mathrm{mmho} / \mathrm{cm}$ & $\mathrm{dS} \cdot \mathrm{m}^{-1}$ & 1 \\
28.3495 & $\mathrm{oz}$ & $\mathrm{g}$ & 0.0353 \\
70.0532 & $\mathrm{oz} / \mathrm{acre}$ & $\mathrm{g} \cdot \mathrm{ha}^{-1}$ & 0.0143 \\
0.9072 & ton $(\mathrm{s})$ & $\mathrm{t}$ & 1.1023 \\
2.2417 & ton $(\mathrm{s}) / \mathrm{acre}$ & $\mathrm{t} \cdot \mathrm{ha}^{-1}$ & 0.4461 \\
$\left({ }^{\circ} \mathrm{F}-32\right) \div 1.8$ & ${ }^{\circ} \mathrm{F}$ & ${ }^{\circ} \mathrm{C}$ & $\left({ }^{\circ} \mathrm{C} \times 1.8\right)+32$
\end{tabular}


mung bean (Vigna radiata) seeded in mid-March (M.S. Bhullar, unpublished data). An effective long-term alternative to triazine for weed management in potato has not been identified.

Overreliance on herbicides and an increased emphasis on sustainable weed control practices, have renewed interest in environmentally benign methods of weed management that rely less on chemicals. In addition, the evolution of herbicide-resistant weeds has renewed interest in the use of nonchemical approaches to suppress weeds. Cultivation and herbicides are the most commonly used weed control methods in potato (Callihan and Bellinder, 1993). Manual hoeing is quite effective but not much effective, since it may cause root injury and disturbs root systems, if performed in the later stages of plant growth (Khurana et al., 1993). Properly timed straw mulch can suppress early germinating annual broadleaf and grass weeds and will be sustainable for a long period of time. Mulch, whether living or dead, inhibits the light necessary for weed shoot emergence and growth, with some types of mulch also exhibiting allelopathic properties (Liebl et al., 1992; Zimdahl, 1999). Straw mulch applied at planting has been shown to suppress weeds in potato, whereas straw applied after cultivation had less effect on weeds (Johnson et al., 2004). Straw mulch has effectively controlled grass and broadleaf weeds in tomato (Solanum lycopersicum), producing yields similar to treated with herbicides (Monks et al., 1997). Straw mulch at $6 \mathrm{t} \cdot \mathrm{ha}^{-1}$ applied 4 weeks after planting increased tuber yield (Kar and Kumar, 2007), with low amounts (2.5$5 \mathrm{t} \cdot \mathrm{ha}^{-1}$ ) of straw mulch not showing any effect on weed suppression and potato yield (Doring et al., 2005). Mulches reduce water evaporation from the soil and help maintain a stable soil temperature ( $\mathrm{Ji}$ and Unger, 2001; Kar and Kumar, 2007; Lal, 1974). Mulching with rice (Oryza sativa) straw at $6 \mathrm{t} \cdot \mathrm{ha}^{-1}$ narrowed down the daily soil temperature amplitude at $5-\mathrm{cm}$ depth in sandy loam soil compared with a no-mulch treatment in Punjab, hence provided favorable hydrothermal regime for growth and development of potato (C.B. Singh, personal communication). Straw mulch also reduces tuber exposure to sunlight, which reduces tuber greening (Bellinder et al., 1996).

The objectives of this research were to determine effect of straw mulch at different rates applied alone or in combination with reduced rate of atrazine, atrazine at registered rate, and mechanical weed control on the suppression of weeds, and potato tuber weight and yield.

\section{Materials and methods}

Field experiments were conducted at Agronomy Research Station, Punjab Agricultural University, Ludhiana, India (lat. $30^{\circ} 56^{\prime} \mathrm{N}$, long. $75^{\circ} 52^{\prime} \mathrm{E}$ ) for 4 years during 2006 to 2010 growing seasons. The experimental soil was loamy sand with a $\mathrm{pH}$ of $7.8,0.27 \%$ organic carbon, 215 $\mathrm{kg} \cdot \mathrm{ha}^{-1}$ nitrogen $(\mathrm{N}), 22.8 \mathrm{~kg} \cdot \mathrm{ha}^{-1}$ phosphorus (P), $255 \mathrm{~kg} \cdot \mathrm{ha}^{-1}$ potassium $(\mathrm{K})$, and $0.20 \mathrm{dS} \cdot \mathrm{m}^{-1}$ electrical conductivity. The experiment was arranged in a randomized complete block design with four replications.

The seedbed was prepared by one ploughing with disc harrow followed by planking. An early maturing potato cultivar Kufri Chandarmukhi was planted during 4 years. The potato tubers were dipped in a $0.25 \%$ solution of methoxy ethyl mercury chloride (Emisan-6; Excel Crop Care, Mumbai, India) for $30 \mathrm{~min}$ to protect them from soilborne fungi and bacteria. Treated tubers were dried under shade area. To improve germination, the tubers were kept in an aerated place for 8 to $10 \mathrm{~d}$ before planting. Potato tubers at $4 \mathrm{t} \cdot \mathrm{ha}^{-1}$ were planted at $20-\mathrm{cm}$ spacing in moist soil at the base of $60-\mathrm{cm}$ spaced ridges. The planting was accomplished on 26 Oct. 2006, 20 Oct. 2007, 12 Oct. 2008 , and 9 Oct. 2009. The plot size was $4 \times 9 \mathrm{~m}$ and comprised of eight rows of potato.

The crop was fertilized with 5 $\mathrm{t} \cdot \mathrm{ha}^{-1}$ farm yard manure, $235 \mathrm{~kg} \cdot \mathrm{ha}^{-1}$ $\mathrm{N}, 62.5 \mathrm{~kg} \cdot \mathrm{ha}^{-1} \mathrm{P}$, and $62.5 \mathrm{~kg} \cdot \mathrm{ha}^{-1} \mathrm{~K}$. The $\mathrm{N}$ was applied in the form of urea $(46 \%), \mathrm{P}$ in the form of single super phosphate $(16 \%)$, and $\mathrm{K}$ in the form of muriate of potash $(60 \%)$. The farm yard manure was applied 1 week before planting and incorporated with the last ploughing. Total quantity of $\mathrm{P}$ and $\mathrm{K}$ fertilizers and half $\mathrm{N}$ was drilled at the time of planting; half $\mathrm{N}$ was broadcasted $\mathrm{I}$ month after planting. The field was irrigated immediately after planting and six to seven times during the crop season. Weed control treatments included atrazine (Atracel, Excel Crop Care) at $250 \mathrm{~g} \cdot \mathrm{ha}^{-1}$, and rice straw mulch at $4,5,6$, and $7 \mathrm{t} \cdot \mathrm{ha}^{-1}$ applied alone or in combination with atrazine at $125 \mathrm{~g} \cdot \mathrm{ha}^{-1}$. An untreated control and hand hoeing at 20 and $40 \mathrm{~d}$ after planting were included for comparison (Table 1). Atrazine was sprayed as a preemergence treatment on the third day of planting potato using a knapsack sprayer fitted with flat fan nozzles with a spray volume of 500 $\mathrm{L} \cdot \mathrm{ha}^{-1}$. Straw mulch was uniformly spread on the same or following day of atrazine application.

Visual control estimates of different weed species were determined at $30 \mathrm{~d}$ after atrazine treatment based on a $0 \%$ to $100 \%$ scale, with $0 \%$ being no control and $100 \%$ being complete control of weed species. Weed densities were assessed during the growing season within $0.25-\mathrm{m}^{2}$ quadrants (two quadrants per plot) at $60 \mathrm{~d}$ after atrazine treatment, and the biomass cut of weeds was taken at $60 \mathrm{~d}$ after herbicide treatment. The weeds within randomly selected $0.25-\mathrm{m}^{2}$ quadrants (two quadrants per plot) were cut at the stem base close to the soil surface, placed in paper bags, dried in an oven for $72 \mathrm{~h}$ at $60{ }^{\circ} \mathrm{C}$, and weight of biomass was recorded. Data of fresh weight of tubers per plant were recorded from five randomly selected plants, 3 to $4 \mathrm{~d}$ before crop harvest. The crop was harvested manually on 28 Jan. 2007, 23 Jan. 2008, 6 Feb. 2009, and I Feb. 2010, and tuber yield was recorded.

Data were subjected to analysis of variance (ANOVA) using PROC MIXED procedure in SAS (version 9.2; SAS Institute, Cary, NC). Normality, homogeneity of variance, and interactions of treatments and years were tested. A preliminary data analysis suggested that year $\times$ treatment interaction was nonsignificant; therefore, treatments were considered as the fixed effects, while year (nested within replication) was considered a random effect in a model. Considering year as a random effect in the model allows inferences about treatments over a wide range of environments (Blouin et al., 2011). Data of visual control estimates and weed density were arcsine square root transformed before analysis; however, 
Table 1. Effect of atrazine and/or straw mulch treatments on weed control at $30 \mathrm{~d}$ after herbicide treatments in a field experiment conducted for 4 years in potato in Punjab, India. ${ }^{\mathrm{z}}$

\begin{tabular}{|c|c|c|c|c|c|c|c|}
\hline \multirow[b]{2}{*}{ Treatment $^{\mathrm{y}}$} & $\begin{array}{l}\text { Littleseed } \\
\text { canarygrass }\end{array}$ & Burclover & $\begin{array}{l}\text { Toothed } \\
\text { dock }\end{array}$ & $\begin{array}{c}\text { Common } \\
\text { lambsquarters }\end{array}$ & $\begin{array}{c}\text { Scarlet } \\
\text { pimpernel }\end{array}$ & Swinecress & $\begin{array}{c}\text { Purple } \\
\text { nutsedge }\end{array}$ \\
\hline & \multicolumn{7}{|c|}{ Control $(\%)^{x}$} \\
\hline Untreated control $^{\mathrm{w}}$ & 0 & 0 & 0 & 0 & 0 & 0 & 0 \\
\hline Hand hoeing (twice) & $88 a^{v}$ & $99 \mathrm{a}$ & $80 \mathrm{~b}$ & $78 \mathrm{c}$ & $74 \mathrm{~b}$ & $70 \mathrm{a}$ & $58 \mathrm{a}$ \\
\hline Atrazine $250 \mathrm{~g} \cdot \mathrm{ha}^{-1}$ & $75 \mathrm{~b}$ & $70 \mathrm{c}$ & $78 \mathrm{~b}$ & $75 \mathrm{c}$ & $76 \mathrm{~b}$ & $55 \mathrm{~b}$ & $0 \mathrm{c}$ \\
\hline Straw mulch $4 \mathrm{t} \cdot \mathrm{ha}^{-1}$ & $70 \mathrm{~b}$ & $68 c$ & $90 \mathrm{ab}$ & $75 \mathrm{c}$ & $75 \mathrm{~b}$ & $71 \mathrm{a}$ & $35 \mathrm{~b}$ \\
\hline Straw mulch $7 \mathrm{t} \cdot \mathrm{ha}^{-1}$ & $75 \mathrm{~b}$ & $82 \mathrm{~b}$ & $92 \mathrm{ab}$ & $90 \mathrm{ab}$ & $98 \mathrm{a}$ & $75 \mathrm{a}$ & $55 \mathrm{a}$ \\
\hline $\begin{array}{l}\text { Atrazine } 125 \mathrm{~g} \cdot \mathrm{ha}^{-1} \text { and } \\
\text { straw mulch } 4 \mathrm{t} \cdot \mathrm{ha}^{-1}\end{array}$ & $90 \mathrm{a}$ & $94 \mathrm{a}$ & $99 \mathrm{a}$ & 98 a & $98 \mathrm{a}$ & $78 \mathrm{a}$ & $56 \mathrm{a}$ \\
\hline $\begin{array}{l}\text { Atrazine } 125 \mathrm{~g} \cdot \mathrm{ha}^{-1} \text { and } \\
\text { straw mulch } 5 \mathrm{t} \cdot \mathrm{ha}^{-1}\end{array}$ & $88 \mathrm{a}$ & $99 \mathrm{a}$ & $99 \mathrm{a}$ & $99 \mathrm{a}$ & $99 \mathrm{a}$ & $75 \mathrm{a}$ & $55 \mathrm{a}$ \\
\hline $\begin{array}{l}\text { Atrazine } 125 \mathrm{~g} \cdot \mathrm{ha}^{-1} \text { and } \\
\text { straw mulch } 6 \mathrm{t} \cdot \mathrm{ha}^{-1}\end{array}$ & $89 \mathrm{a}$ & $99 \mathrm{a}$ & $99 \mathrm{a}$ & $99 \mathrm{a}$ & $99 \mathrm{a}$ & $77 \mathrm{a}$ & $55 \mathrm{a}$ \\
\hline \multicolumn{8}{|c|}{$\begin{array}{l}{ }^{2} \text { Visual control estimates of different weed species were determined at } 30 \mathrm{~d} \text { after atrazine treatment based on a } 0 \% \text { to } 100 \% \text { scale, with } 0 \% \text { being no control and } 100 \% \text { being } \\
\text { complete control of weed species. } \\
{ }^{y} 1 \mathrm{~g} \cdot h a^{-1}=0.0143 \mathrm{oz} / \mathrm{acre}, 1 \mathrm{t} \cdot \mathrm{ha}^{-1}=0.446 \mathrm{l} \text { ton/acre. }\end{array}$} \\
\hline
\end{tabular}

nontransformed means are presented with mean separation based on transformed values. Where the ANOVA indicated treatment effects were significant, means were separated at $P \leq$ 0.05 and adjusted with Fisher's protected least significant difference test.

\section{Results and discussion}

Common weed species infesting experimental sites during the 4-year study were burclover, common lambsquarters, littleseed canarygrass, purple nutsedge, red pimpernel, swinecress, and toothed dock. Atrazine applied alone at $250 \mathrm{~g} \cdot \mathrm{ha}^{-1}$ resulted in $75 \%$ to $78 \%$ weed control, except purple nutsedge $(0 \%$ control $)$ at $30 \mathrm{~d}$ after treatment (Table 1) and it was usually comparable with straw mulch applied at $4 \mathrm{t} \cdot \mathrm{ha}^{-1}$. Similarly, several studies reported marginal weed control using atrazine applied alone (Williams et al., 2010 ) that can be enhanced by tankmixing with other herbicides such as 4-hydroxyphenylpyruvate dioxygenase inhibiting herbicides in cereal crops (Swanton et al., 2007; Williams et al., 2011); however, limited herbicides are registered in potato that reduces possibility of herbicide tank mixtures. Sharma et al. (2004) reported better control of broadleaf weeds compared with grass weeds when atrazine was applied at 1 or
$1.25 \mathrm{~kg} \cdot \mathrm{ha}^{-1}$ in potato. Application of straw mulch alone at different rates resulted in variable control $(0 \%$ to 99\%) depending on the species being investigated. For example, control of toothed dock was $>90 \%$ with no significant difference between rates of straw mulch application, while relatively less control $(70 \%$ to $82 \%)$ was observed for other weeds with straw mulch-only treatments. The height of the straw mulch was $1.7 \mathrm{~cm}$ for $4 \mathrm{t} \cdot \mathrm{ha}^{-1}$ straw much treatment, and subsequently more for higher rates. Bushnell and Welton (1931) found that at application levels below $19 \mathrm{t} \cdot \mathrm{ha}^{-1}$, annual weeds penetrated mulch later in the season. Similarly, Hembry and Davies (1994) reported new weed growth later in the season even with the application of straw mulch at $20 \mathrm{t} \cdot \mathrm{ha}^{-1}$.

A combination of reduced rate of atrazine $\left(125 \mathrm{~g} \cdot \mathrm{ha}^{-1}\right)$ and straw mulch resulted in $88 \%$ to $99 \%$ control of burclover, common lambsquarters, littleseed canarygrass, and scarlet pimpernel at $30 \mathrm{DAT}$. A reduced rate of atrazine is particularly important to avoid carry over injury to the crops grown in rotation with potato including vegetables, pulses, or oilseed crops in Punjab (Sharma and Sandhu, 1985). Weed control was reduced later in the season due to reduced residual activity of atrazine and partial loss of mulch layers from the soil surface. Additionally, supplemental irrigation provided opportunity for purple nutsedge and common lambsquarters to emerge later in the season (90 d after planting). Control of swine cress and purple nutsedge was $<78 \%$ and $62 \%$, respectively, in all treatments at 30 DAT. Similarly, Chen et al. (2013) found that relative to bare soil, mulching provided $40 \%$ to $60 \%$ control of yellow nutsedge. Several studies have also reported partial control of nutsedge using mulch (Broschat, 2007; Johnson and Fennimore, 2006; Norsworthy and Meehan, 2005). This is also because purple nutsedge is a perennial weed and has ability to reproduce through tubers. A single plant is capable of producing 19,000 to 22,000 tubers in 1 year (Ransom et al., 2009). Bangarwa et al. (2008) reported that a season-long management that may include frequent tillage, use of a translucent polyethylene film is essential to prevent purple nutsedge proliferation over time. It was clear that a combination of atrazine and straw mulch provided acceptable control of several, but not all weed species, and additional methods are required for broad-spectrum, seasonlong weed control in potato. 
Table 2. Effect of atrazine and/or straw mulch treatments on weed density and biomass at $60 \mathrm{~d}$ after planting in a field experiment conducted for 4 years in potato in Punjab, India. ${ }^{\mathrm{z}}$

\begin{tabular}{|c|c|c|c|c|c|c|c|c|}
\hline \multirow[b]{2}{*}{ Treatment $^{\mathrm{y}}$} & $\begin{array}{c}\text { Littleseed } \\
\text { canarygrass }\end{array}$ & Burclover & $\begin{array}{l}\text { Toothed } \\
\text { dock }\end{array}$ & $\begin{array}{c}\text { Common } \\
\text { lambsquarters }\end{array}$ & $\begin{array}{c}\text { Scarlet } \\
\text { pimpernel }\end{array}$ & Swinecress & $\begin{array}{c}\text { Purple } \\
\text { nutsedge }\end{array}$ & Weed biomass \\
\hline & \multicolumn{7}{|c|}{ Density $\left(\text { plants } / \mathrm{m}^{2}\right)^{\mathrm{x}}$} & $\left(\mathrm{g} \cdot \mathrm{m}^{-2}\right)$ \\
\hline Untreated control & $56.0 \mathrm{a}^{\mathrm{w}}$ & $10.4 \mathrm{a}$ & $10.3 \mathrm{a}$ & $20.0 \mathrm{a}$ & $8.0 \mathrm{a}$ & $28.1 \mathrm{a}$ & $94.8 \mathrm{ab}$ & $450 \mathrm{a}$ \\
\hline Hand hoeing (twice) & $5.3 \mathrm{c}$ & $3.0 \mathrm{~cd}$ & $6.0 \mathrm{c}$ & $17.3 \mathrm{a}$ & $8.0 \mathrm{a}$ & $8.5 \mathrm{~b}$ & $59.2 \mathrm{bc}$ & $130 \mathrm{~d}$ \\
\hline Atrazine $250 \mathrm{~g} \cdot \mathrm{ha}^{-1}$ & $15.3 \mathrm{bc}$ & $8.3 \mathrm{ab}$ & $2.0 \mathrm{bc}$ & $2.0 \mathrm{bc}$ & $2.7 \mathrm{~b}$ & $10.4 \mathrm{~b}$ & $130.2 \mathrm{a}$ & $400 \mathrm{~b}$ \\
\hline Straw mulch $4 \mathrm{t} \cdot \mathrm{ha}^{-1}$ & $26.3 \mathrm{~b}$ & $6.3 \mathrm{abc}$ & $2.0 \mathrm{bc}$ & $4.0 \mathrm{~b}$ & $2.7 \mathrm{~b}$ & $9.4 \mathrm{~b}$ & $46.9 \mathrm{c}$ & $300 \mathrm{c}$ \\
\hline Straw mulch $7 \mathrm{t} \cdot \mathrm{ha}^{-1}$ & $18.7 \mathrm{bc}$ & $0 \mathrm{~d}$ & $1.3 \mathrm{bc}$ & $1.3 \mathrm{bc}$ & $1.3 \mathrm{~b}$ & $6.4 \mathrm{~b}$ & $22.9 \mathrm{c}$ & $310 \mathrm{c}$ \\
\hline $\begin{array}{l}\text { Atrazine } 125 \mathrm{~g} \cdot \mathrm{ha}^{-1} \text { and } \\
\text { straw mulch } 4 \mathrm{t} \cdot \mathrm{ha}^{-1}\end{array}$ & $17.0 \mathrm{bc}$ & $0 \mathrm{~d}$ & $0 \mathrm{c}$ & $0.7 \mathrm{bc}$ & $0 \mathrm{~b}$ & $8.3 \mathrm{~b}$ & $29.2 \mathrm{c}$ & $140 \mathrm{~d}$ \\
\hline $\begin{array}{l}\text { Atrazine } 125 \mathrm{~g} \cdot \mathrm{ha}^{-1} \text { and } \\
\quad \text { straw mulch } 5 \mathrm{t} \cdot \mathrm{ha}^{-1}\end{array}$ & $11.7 \mathrm{bc}$ & $2.3 \mathrm{~cd}$ & $0 \mathrm{c}$ & $0 \mathrm{c}$ & $0 \mathrm{~b}$ & $5.2 \mathrm{~b}$ & $34.8 \mathrm{c}$ & $120 \mathrm{~d}$ \\
\hline $\begin{array}{l}\text { Atrazine } 125 \mathrm{~g} \cdot \mathrm{ha}^{-1} \text { and } \\
\text { straw mulch } 6 \mathrm{t} \cdot \mathrm{ha}^{-1}\end{array}$ & $14.0 \mathrm{bc}$ & $3.1 \mathrm{~cd}$ & $0 \mathrm{c}$ & $0 \mathrm{c}$ & $0 \mathrm{~b}$ & $8.3 \mathrm{~b}$ & $29.2 \mathrm{c}$ & $150 \mathrm{~d}$ \\
\hline
\end{tabular}

${ }^{2}$ Weed densities were assessed during the growing season within $0.25-\mathrm{m}^{2}\left(2.691 \mathrm{ft}^{2}\right)$ quadrants (two quadrants per plot) at $60 \mathrm{~d}$ after atrazine treatment.

${ }^{\mathrm{y}} \mathrm{l} \mathrm{g} \cdot \mathrm{m}^{-2}=0.0033 \mathrm{oz} / \mathrm{ft}^{2}, \mathrm{lt} \cdot \mathrm{ha}^{-1}=0.4461 \mathrm{ton} /$ acre.

${ }^{x}$ Data were arc-sine square-root transformed before analysis; however, back-transformed actual mean values are presented based on the interpretation from the transformed data; 1 plant $/ \mathrm{m}^{2}=0.0929$ plant $/ \mathrm{ft}^{2}$.

${ }^{w}$ Means presented within each column with no common letter(s) are significantly different according to Fisher's protected least significant difference test where $P \leq 0.05$.

Weed density was affected by atrazine and/or mulch treatments and usually reflected the results of visual weed control estimates. The highest weed density and biomass was usually recorded in untreated control plots (Table 2). Atrazine applied alone resulted in weed density ranging from 2 to 130 plants $/ \mathrm{m}^{2}$ at 60 DAT, which was usually comparable with straw mulch applied alone with some variability in their application rates. Although not significantly different from some other treatments, a combination of atrazine and straw mulch resulted in no emergence of common lambsquarters, red pimpernel, and toothed dock at 60 DAT. This indicates that atrazine applied preemergence followed by straw mulch adequately suppressed these weed species. Purple nutsedge is a troublesome weed in potato production in northwest India, and was the most difficult to control compared with all other weed species in this study as reflected in the density of $>20$ plants $/ \mathrm{m}^{2}$ in all treatments.

Due to weed competition, the untreated control resulted in the lowest tuber weight $(267 \mathrm{~g} /$ plant $)$ and yield $\left(13.06 \mathrm{t} \cdot \mathrm{ha}^{-1}\right)$ compared with other treatments; however, no difference was observed among treatments of mulching, atrazine, and combinations of atrazine and mulching (Table 3 ). Results of this study suggest that

Table 3. Effect of atrazine and/or straw mulch treatments on potato tuber weight and tuber yield in a field experiment conducted for $\mathbf{4}$ years in potato in Punjab, India.

\begin{tabular}{|c|c|c|}
\hline Treatment $^{\mathrm{z}}$ & Tuber wt $(\mathrm{g} / \text { plant })^{\mathrm{z}}$ & $\begin{array}{c}\text { Tuber yield } \\
\left(t \cdot h a^{-1}\right)^{z}\end{array}$ \\
\hline Untreated control & $267 b^{y}$ & $13.06 \mathrm{~b}$ \\
\hline Hand hoeing (twice) & $440 \mathrm{a}$ & $19.40 \mathrm{a}$ \\
\hline Atrazine $250 \mathrm{~g} \cdot \mathrm{ha}^{-1}$ & $388 \mathrm{a}$ & $18.54 \mathrm{a}$ \\
\hline Straw mulch $4 \mathrm{t} \cdot \mathrm{ha}^{-1}$ & $393 \mathrm{a}$ & $19.03 \mathrm{a}$ \\
\hline Straw mulch $5 \mathrm{t} \cdot \mathrm{ha}^{-1}$ & $420 \mathrm{a}$ & $19.62 \mathrm{a}$ \\
\hline Straw mulch $6 \mathrm{t} \cdot \mathrm{ha}^{-1}$ & $413 \mathrm{a}$ & $19.35 \mathrm{a}$ \\
\hline Straw mulch $7 \mathrm{t} \cdot \mathrm{ha}^{-1}$ & $410 \mathrm{a}$ & $19.45 \mathrm{a}$ \\
\hline Atrazine $125 \mathrm{~g} \cdot \mathrm{ha}^{-1}$ and straw mulch $4 \mathrm{t} \cdot \mathrm{ha}^{-1}$ & $387 \mathrm{a}$ & $19.32 \mathrm{a}$ \\
\hline Atrazine $125 \mathrm{~g} \cdot \mathrm{ha}^{-1}$ and straw mulch $5 \mathrm{t} \cdot \mathrm{ha}^{-1}$ & $410 \mathrm{a}$ & $19.07 \mathrm{a}$ \\
\hline Atrazine $125 \mathrm{~g} \cdot \mathrm{ha}^{-1}$ and straw mulch $6 \mathrm{t} \cdot \mathrm{ha}^{-1}$ & $430 \mathrm{a}$ & $19.78 \mathrm{a}$ \\
\hline Atrazine $125 \mathrm{~g} \cdot \mathrm{ha}^{-1}$ and straw mulch $7 \mathrm{t} \cdot \mathrm{ha}^{-1}$ & $412 \mathrm{~b}$ & $19.04 \mathrm{a}$ \\
\hline
\end{tabular}

${ }^{\mathrm{z}} \mathrm{l} \mathrm{g} \cdot \mathrm{ha}^{-1}=0.0143 \mathrm{oz} / \mathrm{acre}, \mathrm{l} \mathrm{t} \cdot \mathrm{ha}^{-1}=0.446 \mathrm{l}$ ton/acre, $\mathrm{l} \mathrm{g}=0.0353 \mathrm{oz}$.

'Means presented within each column with no common letter(s) are significantly different according to Fisher's protected least significant difference test where $P \leq 0.05$.

a combination of a reduced rate of atrazine $\left(125 \mathrm{~g} \cdot \mathrm{ha}^{-1}\right)$ and straw mulch were effective for controlling weeds and reducing weed density as low as 0 plant $/ \mathrm{m}^{2}$ for selected species. The results were in agreement with several studies reported previously that straw mulch is effective in suppressing weed growth and reducing the need for postemergence herbicides; however, their effect on crop yields is variable (Chalker-Scott, 2007; Chen et al., 2013). In this research, differences in weed control between mulch and/or atrazine treatments did not result in crop yield differences. Additionally, no benefit of increasing application rate of straw mulch was observed on potato yields; however, straw mulch may have effect on other variables such as soil erosion. The benefits of straw mulch on soil erosion and virus control are obtained at considerably lower levels. For example, 1.5 to $2.5 \mathrm{t} \cdot \mathrm{ha}^{-1}$ of straw mulch was found to control erosion to a large extent (Lal 1987; Nill and Nill, 1993).

\section{Conclusion}

Results of this study suggested that compared with untreated control, all mulch and/or atrazine treatments were effective controlling weeds in potato, with varying extents 
of efficacy among them. However, potato yield was not significantly different when the different mulch and/ or atrazine treatments were used. More research is required for management of purple nutsedge not only in potato but also in several vegetable crops grown under irrigation in Punjab, India.

\section{Literature cited}

Ahuja, K.N., N.T. Yaduraju, R. Singh, and D.K. Singh. 1999. Chemical weed control in potato (Solanum tuberosum L.). Indian J. Weed Sci. 31:8-12.

Bangarwa, S.K., J.K. Norsworthy, P. Jha, and M.S. Malik. 2008. Purple nutsedge (Cyperus rotundus) management in an organic production system. Weed Sci. 56:606-613.

Bellinder, R.R., R.W. Wallace, and E.D. Wilkins. 1996. Reduced rates of herbicides following hilling controlled weeds in conventional and reduced tillage potato (Solanum tuberosum L.) production. Weed Technol. 10:311-316.

Blouin, D.C., E.P. Webster, and J.A. Bond. 2011. On the analysis of combined experiments. Weed Technol. 25:165-169.

Broschat, T.K. 2007. Effects of mulch type and fertilizer placement on weed growth and soil $\mathrm{pH}$ and nutrient content. HortTechnology 17:174-177.

Bushnell, J. and F.A. Welton. 1931. Some effect of straw mulch on yield of potatoes. J. Agr. Res. 43:837-845.

Callihan, R.H. and R.R. Bellinder. 1993. Management of weeds, p. 95-102. In: R.C. Rove (ed.). Potato health management. APS Press, St. Paul, MN.

Chalker-Scott, L. 2007. Impact of mulches on landscape plants and the environment: A review. J. Environ. Hort. 25:239-249.

Chen, Y., R.E. Strahan, and R.P. Bracy. 2013. Effects of mulching and preemergence herbicide placement on yellow nutsedge control and ornamental plant quality in landscape beds. HortTechnology 23:651658.

Dallyn, S.L. 1971. Weed control methods in potatoes. Amer. Potato J. 48:116-128.

Doring, T.F., M. Brandt, J. Hesz, M.R. Finckh, and H. Saucke. 2005. Effects of straw mulch on soil nitrate dynamics, weeds, yield and soil erosion in organically grown potatoes. Field Crops Res. 94: 238-249.
Government of India. 2013. Agricultural Situation in India 2013. 9 Nov. 2014. <http://eands.dacnet.nic.in/ publications $2013 . \mathrm{htm}>$.

Hembry, J.K. and J.S. Davies. 1994 Using mulches for weed control and preventing leaching of nitrogen fertilizer. Acta Hort. 371:311-317.

Ji, S. and P.W. Unger. 2001. Soil water accumulation under different precipitation potential evaporation and straw mulch conditions. Soil Sci. Soc. Am. J. 65:442448.

Johnson, J.M., J.A. Hough-Goldstein, and M.J. Vangessel. 2004. Effects of straw mulch on pest insects, predators and weeds in watermelons and potatoes. Environ. Entomol. 33:1632-1643.

Johnson, M.K. and S.A. Fennimore. 2006. Weed and crop response to colored plastic mulches in strawberry production. HortScience 40:1371-1375.

Kar, G. and A. Kumar. 2007. Effects of irrigation and straw mulch on water use and tuber yield of potato in eastern India. Agr. Water Mgt. 94:109-116.

Khurana, S.C., K.K. Thakral, and A.K. Bhatia. 1993. Effect of pendimethalin and isoproturon on weeds and tuber yield in potato. J. Indian Potato Assn. 20:255257.

Lal, R. 1974. Soil temperature, soil moisture and maize yield from mulched and unmulched tropical soils. Plant Soil 40:129-143.

Lal, R. 1987. Tropical ecology and physical edaphology. Wiley, Hoboken, NJ.

Liebl, R., F.W. Simmons, L.M. Wax, and E.W. Stoller. 1992. Effect of rye (Setaria cereale) mulch on weed control and soil moisture in soybean (Glycine max). Weed Technol. 6:838-846.

Monks, C.D., D.W. Monks, T. Basden, A. Selders, S. Poland, and E. Rayburn. 1997. Soil temperature, soil moisture, weed control, and tomato (Lycopersicon esculentum) response to mulching. Weed Technol. 11:561-566.

Monteiro, A., I. Henriques, and I. Moreira. 2011. Critical period for weed control in potatoes in the Huambo Province (Angola). Planta Daninha 29:351-362.

Nelson, D.C. and M.C. Thoreson. 1981. Competition between potatoes (Solanum tuberosum) and weeds. Weed Sci. 29:672677.

Nill, D. and E. Nill. 1993. The efficient use of mulch layers to reduce runoff, p. 331338. In: K. Mulongoy and R. Merckx (eds.). Soil organic matter dynamics and sustainability of tropical agriculture. Wiley, New York, NY.

Norsworthy, J.K. and T.J. Meehan. 2005. Wild-radish amended soil effects on yellow nutsedge (Cyperus esculentus) interference with tomato and bell pepper. Weed Sci. 53:77-83.

Pandey, A.K. 2000. Weed management in vegetable crop, p. 132-138. Proc. Natl. Training Course on Vegetable Production. Indian Institute of Vegetable Research, Varanasi, India.

Ransom, C.V., C.A. Rice, and C.C. Shock. 2009. Yellow nusedge (Cyperus esculentus) growth and reproduction in response to nitrogen and irrigation. Weed Sci. 57:21-25.

Sharma, J.J., G.D. Sharma, and S. Sood. 2004. Weed management in potato under dry temperate agro-ecosystem (HP). Potato J. 31:55-58.

Sharma, R.K. and K.S. Sandhu. 1985. Residual effect of atrazine and simazine applied to fodder maize sown on different dates on the succeeding wheat. Indian J. Weed Sci. 17:29-34.

Singh, V.P. and V.M. Bhan. 1999. Herbicidal control of weeds in potato (Solanum tuberosum L.) in Vertisol. Indian J. Weed Sci. 31:214-217.

Swanton, C.J., R.H. Gulden, and K. Chandler. 2007. A rationale for atrazine stewardship in corn. Weed Sci. 55:75-81.

Wall, D.A. and D.H. Friesen. 1990. Effect of duration of green foxtail (Setaria viridis) competition on potato (Solanum tuberosum L.) yield. Weed Technol. 4:539-542.

Williams, M.M., C.M. Boerboom, and T.L. Rabaey. 2010. Significance of atrazine in sweet corn weed management system. Weed Technol. 24:139-142.

Williams, M.M., R.A. Boydston, R.E. Peachey, and D. Robinson. 2011. Significance of atrazine as a tank-mix partner with tembotrione. Weed Technol. 25:299302.

Zimdahl, R.L. 1999. Fundamentals of weed science. Academic Press, New York. NY. 